\title{
Bond strength of epoxy coated bar splices confined with nominal lateral reinforcement
}

Research Article

\author{
Krishnamurthy Pandurangan ${ }^{1 *}$, Gangolu Appa Rao ${ }^{2}$ \\ 1 Department of Civil Engineering, Pondicherry Engineering College, Puducherry, India \\ 2 Department of Civil Engineering, Indian Institute of Technology, Madras, Chennai - 600 036, India
}

Received 07 April 2012; accepted 16 August 2012

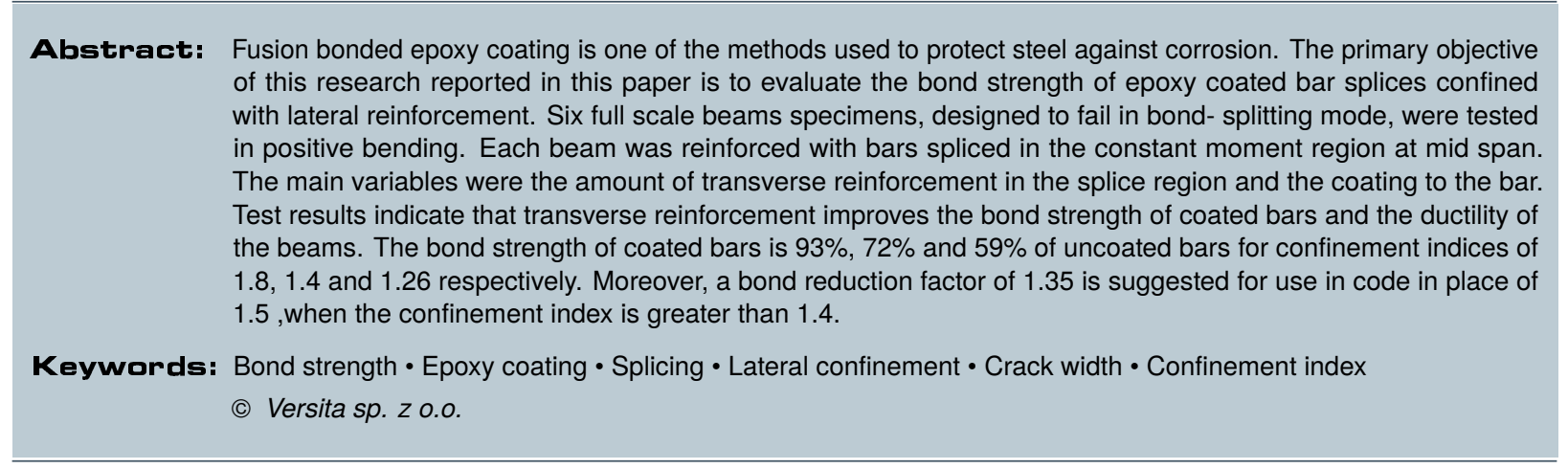

\section{Introduction}

Corrosion is a process that increases gradually with time. In reinforced concrete, the volume occupied by corrosion products is as much as 20 to 30 times the original volume of steel. The pressure due to this volume expansion induces cracks in the surrounding concrete, which aggravates further corrosion of steel and results in total loss of interaction between steel and concrete. A solution to minimize such corrosion problems is to apply protective coating on reinforcing steel. The most popular one is the fusion bonded epoxy coating. The epoxy coating reduces

*E-mail: pandu@pec.edu the bond between the reinforcement and concrete. Bond in reinforced concrete is described by three components viz., chemical adhesion, friction and mechanical interaction between the bar ribs and the surrounding concrete. The resultant of these forces act inclined to the bar and can be resolved into two components viz., radial force and bond force as shown in Figure 1. In coated bars the frictional resistance seems to be low and hence the bond force decreases. Treece and Jirsa [1] completely ignored the frictional resistance of coated bars, while developing a failure hypothesis for the bond strength of coated bars. However, studies on coated and uncoated plates by Cairns and Abdullah [2] show that the average coefficient of friction with uncoated and coated bars is 0.52 and 0.46 respectively. The low frictional resistance 

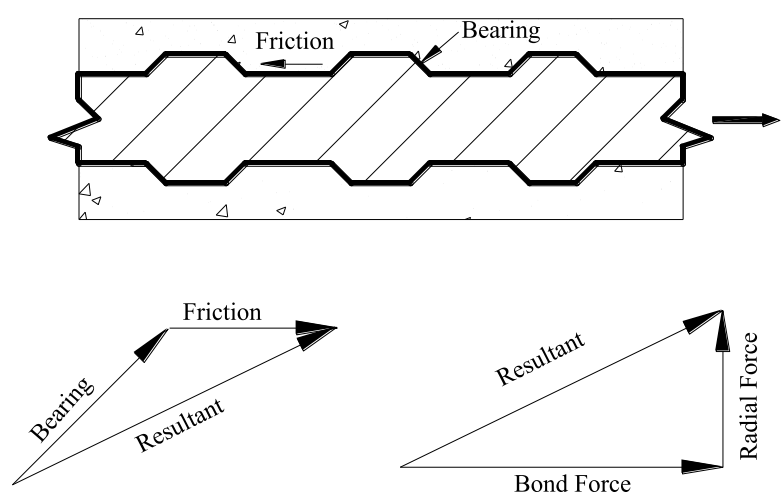

Figure 1. Transfer of forces at the interface.

is due to decrease of the bond strength of coated bars. Based on the experimental results, Cairns and Abdullah [2] report that the ratio of the coefficient of friction of coated and uncoated plates is 0.875 . The coating on bars also lowers the relative rib area and reduces the transfer of force from concrete to the reinforcing bar due to decrease in mechanical interaction. The coating on the bar is a weak layer between the reinforcement and the surrounding concrete. The shear deformation of the coating enhances the slip between the concrete and the reinforcement. Therefore, epoxy coating on the reinforcement influences the bond strength and hence the serviceability of RC structures.

These negative effects of coating could be minimized by 1) providing more splice length; 2) large cover to the reinforcement and 3) lateral confinement over the splice region as reported by $\mathrm{ACl}$ committee 408 [3]. Increasing the cover to the reinforcement can be effective before cracking of concrete. Most of the slip of the reinforcing bar occurs after cracking of the surrounding concrete. After cracking, the lateral confinement provides resistance to slipping of reinforcing bar. Hence, the behavior of the coated bars is improved by providing lap length as required for the uncoated bars with increased confinement. Moreover, overlapping of reinforcing bars with inadequate confinement would cause brittle failure. Hence the epoxy coated lap splices should be provided with adequate confining reinforcement to ensure ductile failure [4-6]. The lateral confinement can be accomplished by transverse steel reinforcement or by fiber reinforcement or FRP wrapping. This paper presents the results of the experimental investigation of transverse reinforcement on the bond strength of spliced fusion bonded epoxy coated bars. in tension and provides a comparative evaluation of the effects of stirrup spacing on the bond strength and ductility of beams with splices.

\section{Review of literature}

The effect of coating thickness has been studied in pull-out tests [7]. With epoxy coating ranging from $0.025 \mathrm{~mm}$ to $0.280 \mathrm{~mm}$ thickness, the bond strength reduces by $6 \%$ of that of the uncoated bars. However, with coating thickness of $0.635 \mathrm{~mm}$, the ultimate bond strength ranges from $34 \%$ and $60 \%$ of that of the uncoated bars. Swamy [7] reported studies on the bendability, corrosion resistance and bond strength of epoxy coated bars in pullout specimens. The coated bars with ribs normal to the axis of the bar exhibited $95 \%$ bond strength of the uncoated bars. However, only $69 \%$ bond strength was achieved with diamond pattern ribs. Ribs inclined with the axis of the bar resulted in reduction of strength about $15 \%$. Treece and Jirsa [1] tested 21 beams with $19 \mathrm{~mm}$ and $36 \mathrm{~mm}$ diameters bars in 28, 55 and $83 \mathrm{MPa}$ concrete. The coating thickness ranged from $0.125 \mathrm{~mm}$ to $0.300 \mathrm{~mm}$ on reinforcing steel with diamond pattern. The splice length was not provided with transverse reinforcement. The results show that with epoxy coating thickness of $0.13 \mathrm{~mm}$, only $67 \%$ bond strength was achieved. The maximum reduction was observed for a coating thickness of $0.275 \mathrm{~mm}$ and the bond strength was $54 \%$ of uncoated bars.

Hester et al. [8] reported the experimental investigation on 36 beam splices with coated and coated bar splices, varying casting position, bar size and anti-bleeding agent in concrete. Steel bars with deformation pattern perpendicular to the axis of the bar resembling bamboo, with epoxy coating thickness of $0.2 \mathrm{~mm}$ were used. The coated bars showed about 84 percent of the bond strength of the uncoated bars. Choi et al. [9] reported the results of 15 beams tested in negative bending with multiple splices in the middle without stirrups in the splice region. Out of the 15 beams tested, four beams were uncoated, to determine the effect of coating on the bond strength. The varying parameters were; bar diameter (16, 25 and $36 \mathrm{~mm}$ ) and bar deformation pattern. The ratio of the bond strength of splices ranged from 0.54 to 0.94 with average value of 0.83 . Hamad and Jirsa [10] tested 12 beams with multiple splices at the center of the beam in negative bending with coating thickness of $0.2 \mathrm{~mm}$. The bond strength of epoxy coated bar splices with $36 \mathrm{~mm}$ diameter bars increased from 74 percent without transverse reinforcement to 80 to 85 percent with transverse reinforcement. The increase was independent of the number of splices or bar spacing. The increase in bond strength was varied from $67 \%$ to $74 \%$ with $20 \mathrm{~mm}$ bars.

Abrishami et al. [11] reported that up to yielding of the reinforcement the epoxy coating does not change the overall load-deflection response of concrete beams. Epoxy coating resulted in few wider cracks, and more splitting cracks. 
Idun and Darwin [12] found that epoxy coating is less detrimental to bond in bars with high relative rib area bars. It was also found that epoxy coating causes less reduction in bond strength with rib face angles greater than 43 degrees. Cairns and Abdullah [13] investigated the bond strength of epoxy coated $16 \mathrm{~mm}$ diameter bars with the following parameters: relative rib area 0.064 , rib inclination 57 and 90 degrees, rib face angle between 30 to 75 degrees, rib spacing $10.8 \mathrm{~mm}$ for factory made bars and $12 \mathrm{~mm}$ for machined bars. The coating thickness ranged from 0.21 to $0.24 \mathrm{~mm}$. The friction between concrete and epoxy coating was less compared with mill scale steel surface by 40 percent at low stress. Hester et al. [8] tested 65 beam and slab specimens. It has been observed that epoxy coating significantly reduces the splice strength. The decrease in splice strength is independent of the degree of transverse reinforcement. As reported in $\mathrm{ACl}$ committee 408 [3], the work of Treece and Jirsa [1] is the basis for the development length modification factors for epoxy coated bars in $\mathrm{ACl} 318$ [14] and the AASHTO bridge specifications [15]. In $\mathrm{ACl} 318$ [14], the development length is multiplied by a factor 1.5 for epoxy coated bars with a cover less than 3 bar diameters or clear spacing between bars less than 6 bar diameter and a factor of 1.2 for other cases, with a maximum factor of 1.7 for the product of top bar factor and epoxy coating factors.

\section{Research significance}

Epoxy coated bars are used since 1980 in reinforced concrete construction to improve the durability of concrete structures. While the corrosion resistance of these bars is good, their bond strength is less than that of uncoated bars. A great deal of research has been done on studying the effect of coating on the bond strength of epoxy coated bars resorting to pullout tests and tests on beams and spliced beam specimens. Moreover, $\mathrm{ACl} 408$ committee used the data available on spliced beams to find the bond reduction factor $\left(\psi_{e}\right)$.Though substantial research was carried out on epoxy coated reinforcement, only a limited data is available on beams with splices. Furthermore, $50 \%$ of the test results on splices are without transverse reinforcement. Stirrups induce a lateral pressure to the bar confined by stirrups and hence will have a positive influence on the bond behavior of coated bars. Most of tests carried out on splices of FBEC bars are confined with stirrups of diameter $12 \mathrm{~mm}$ and $16 \mathrm{~mm}$ spaced very closely as practiced in bridge construction (Hester et al. [8]). However, in multistoried buildings the size of the beam is shallow. Moreover, in reinforced concrete buildings, the size of the bars used as stirrups is $8 \mathrm{~mm}$ and the spacing of stirrups range from

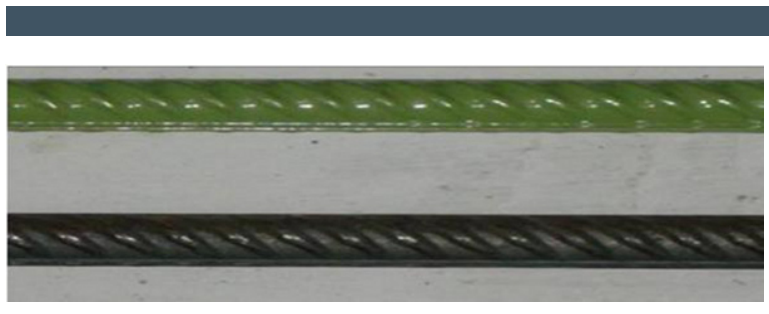

Figure 2. Deformation Pattern of reinforcing bars.

Table 1. Properties of reinforcement.

\begin{tabular}{ccc}
\hline $\begin{array}{c}\text { Bar Diameter, } \\
\mathrm{mm}\end{array}$ & $\begin{array}{c}\text { Yield Stress, } \\
\text { MPa }\end{array}$ & $\begin{array}{c}\text { Ultimate stress, } \\
\text { MPa }\end{array}$ \\
\hline 25 & 520 & 628 \\
20 & 496 & 598 \\
8 & 432 & 515 \\
\hline
\end{tabular}

$100 \mathrm{~mm}$ to $300 \mathrm{~mm}$. This paper reports the effect of lateral confinement on splices under monotonic loading.

\section{Materials}

\subsection{Concrete}

The mix was designed to make concrete with target strength of $60 \mathrm{MPa}$ as per IS10262-2009 [16]. Ordinary Portland Cement (OPC) conforming to IS 12269-1987 [17] was used The fine aggregate conforms to zone III as specified in IS 383-1970 [18]. The mix proportions of the concrete were: Cement: Fine Aggregate: Coarse Aggregate respectively 1: 1.65: 3.00 with a cement content of $400 \mathrm{~kg} / \mathrm{m}^{3}$. The water- cement ratio was 0.35 .

\subsection{Reinforcing steel}

The steel reinforcement used in the beams was Fe 500 grade TMT (Thermo Mechanically Treated) conforming to IS 1786-2008 [19]. The longitudinal steel reinforcement consists of 20 and $25 \mathrm{~mm}$ diameter bars. The rib pattern is shown in Figure 2. The transverse reinforcement was Fe 415 grade steel consisting of $8 \mathrm{~mm}$ diameter two-legged stirrups. The deformation pattern shown in Figure 2 consists of diagonal ribs inclined at an angle of 47 degrees with the axis of the bar. The properties of the steel reinforcement based on the tension test on bars are furnished in Table 1. Epoxy coating on the reinforcing bar surface was applied according to IS 13620-1993 [20]. The thickness of the coating ranges between $0.150 \mathrm{~mm}$ and $0.220 \mathrm{~mm}$ with an average of $0.180 \mathrm{~mm}$, as measured by pull off type thickness gauge. 


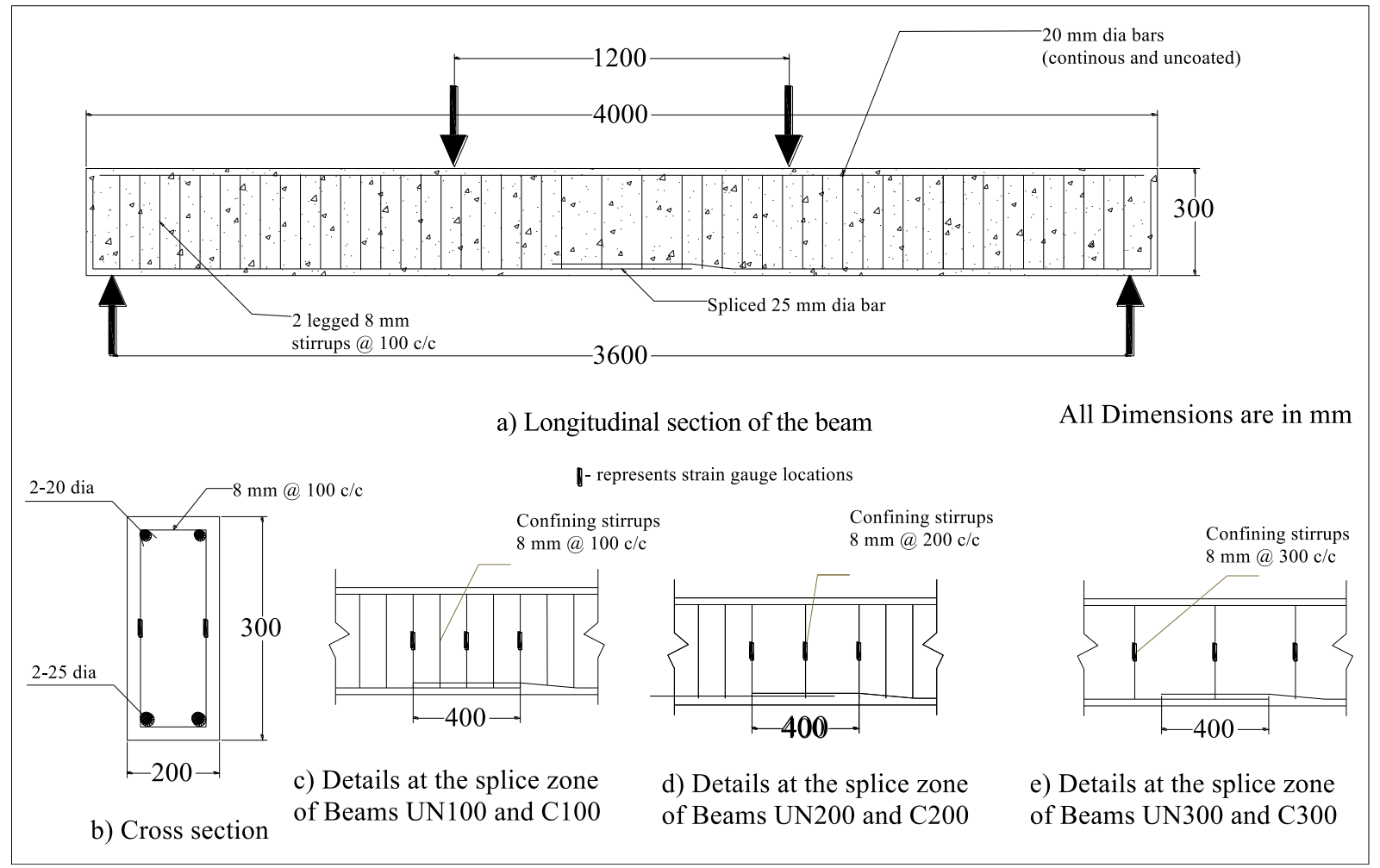

Figure 3. Details of the beam.

\section{Test specimens}

Figure 3 depicts the beam specimen s under investigation. All the beams were $200 \mathrm{~mm}$ wide and $300 \mathrm{~mm}$ deep with a length of $4000 \mathrm{~mm}$. A splice length of $400 \mathrm{~mm}$ (equal to 16 bar diameter) was maintained uniformly in all the beams. The splices were positioned at the center of the beam in the constant moment region of $1.20 \mathrm{~m}$ length. The splice length $\left(L_{d}\right)$ was designed to ensure only the bond failure prior to yielding of the longitudinal steel reinforcement. Concrete cover, $\mathrm{C}$ to reinforcement was $25 \mathrm{~mm}$ in all cases. The cover-to-diameter ratio $\left(C / d_{b}\right)$ was maintained at 1.0 in all the beams to make the splice fail in splitting mode of failure. The clear spacing between the splices was $50 \mathrm{~mm}$. The side cover to the main reinforcement was $25 \mathrm{~mm}$ in all the beams.

Among the six beams prepared, three beams were provided wi8th two longitudinal bars having $25 \mathrm{~mm}$ diameter at the bottom with epoxy coating. The remaining three beams were provided with two $25 \mathrm{~mm}$ diameter uncoated bars at the bottom. The top reinforcement in all the beams consists of two uncoated bars of $20 \mathrm{~mm}$ diameter. All the six beams were provided with transverse reinforcement of two-legged $8 \mathrm{~mm}$ uncoated bars. The spacing between stirrups within the shear span of the beam was maintained @ 100 mm to contain the shear failure of the beams. The effect of confinement on the bond strength of coated and uncoated bars was studied by changing the spacing of stirrups over the lap splice length in the constant moment region. The spacing of the stirrups was $100 \mathrm{~mm} ; 200 \mathrm{~mm}$ and $300 \mathrm{~mm}$ The beams are designated as UNC100, C100, UNC200, C200, UNC300 and C300, where UNC represents the beams with uncoated bars, $C$ represents the beams with coated bars and the number represents the spacing of stirrups in the splice region. The reinforcement details in the beams are given in Table 2. A set of three strain gauges were mounted at three locations along the splice length i.e. loaded, middle and free end of the splice in each of the spliced bars. Strain gauges were mounted on both the legs of three stirrups in the splice region as shown in Figure 3.

\section{Test procedure}

The experimental test setup is shown in Figure 4. The beams were tested under statically determinate supporting system consisting of $50 \mathrm{~mm}$ diameter roller supports. The middle one-third of the beam was subjected to constant moment under four-point loading system. A stiff 
Table 2. Details of the beam.

\begin{tabular}{lccccc}
\hline $\begin{array}{l}\text { Specimen } \\
\text { Designation }\end{array}$ & $L_{d} / d_{b}$ & $C / d_{b}$ & $\begin{array}{c}\text { Compressive Strength, } \\
f_{c m}, \mathrm{MPa}\end{array}$ & $\begin{array}{c}\text { Spacing of } 8 \mathrm{~mm} \text { stirrups } \\
\text { in splice zone, } \mathrm{mm}\end{array}$ & $\begin{array}{c}\text { Spacing of } 8 \mathrm{~mm} \text { Stirrups } \\
\text { in shear span, } \mathrm{mm}\end{array}$ \\
\hline \hline UNC100 & 16 & 1.00 & 53.62 & 100 & 100 \\
C100 & 16 & 1.00 & 53.62 & 100 & 100 \\
UNC200 & 16 & 1.00 & 57.5 & 200 & 100 \\
C200 & 16 & 1.00 & 64.2 & 200 & 100 \\
UNC300 & 16 & 1.00 & 64.2 & 300 & 100 \\
C300 & 16 & 1.00 & 57.5 & 300 & 100 \\
\hline
\end{tabular}

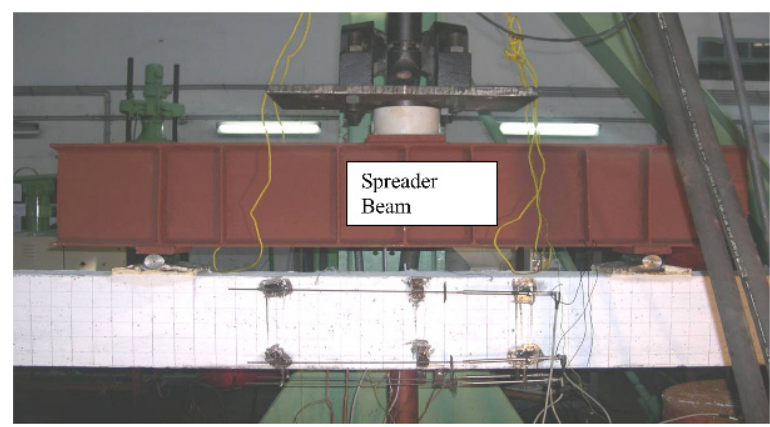

Figure 4. Experimental setup.

spreader beam was used to distribute the total load equally on the beam. Monotonic loading was applied through $500 \mathrm{kN}$ close looped Servo Controlled MTS Actuator with $\pm 100 \mathrm{~cm} / \mathrm{sec}$ velocity, that controls the stroke movement (displacement). The load-deflection response was monitored. The post- peak response was monitored until the load dropped up to about $50 \%$ of the maximum load. The vertical deflection was measured at the centre of the beam at $0.10 \mathrm{~mm}$ increments. A linearly variable differential transducer (LVDT) was fixed to measure the vertical deflection at the centre of the beam. Three sets of LVDT's were arranged to measure the strain in concrete on the extreme top fiber, extreme bottom fiber and also on the tension face of the beam. During testing, progressive cracking of the beams was monitored throughout the test. The spacing of the cracks in the constant moment region was measured at the end of the test. However, the crack width was not measured in this study. Moreover, three cubes were cast with each beam to determine the compressive strength of the beams. These cubes were tested on the day of testing the beams and the mean cube compressive strength of the beams are reported in Table 2 .

\section{Load-deflection response}

The load-deflection response for coated and uncoated tension bar splices confined with 2 legged 8 mm stirrups @

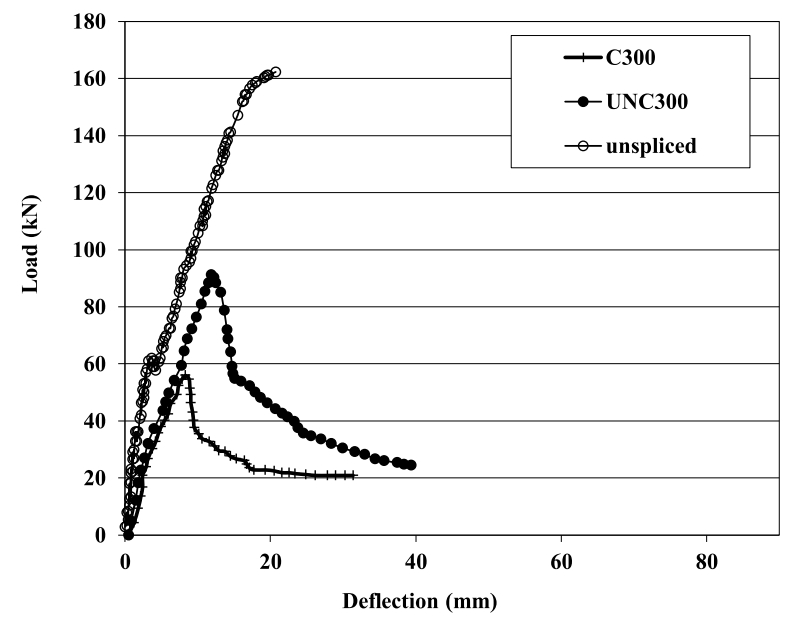

Figure 5. Load-Deflection curves for beams with $8 \mathrm{~mm}$ stirrups spaced@ 300.

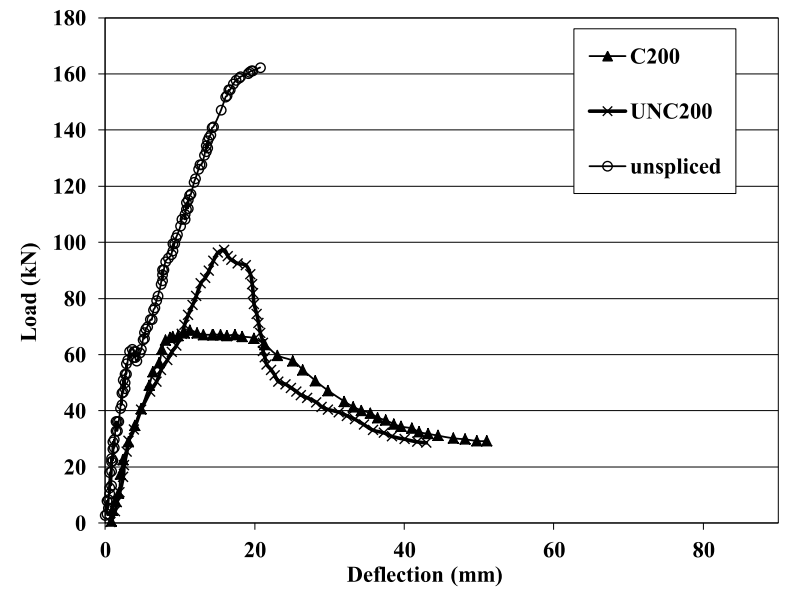

Figure 6. Load-Deflection curves for beams with $8 \mathrm{~mm}$ stirrups spaced@200.

spacing of 300, 200 and 100 is shown in Figures 5, 6 and 7 respectively. The load-deflection response is also compared with the finite element analysis results of the beam without any splicing [21]. The summary of the test results are given in Table 3 . In general, the beams with 
Table 3. Beam test results

\begin{tabular}{lccccccc}
\hline $\begin{array}{l}\text { Specimen } \\
\text { Designation }\end{array}$ & $k_{t r}=A_{t r} f_{y t} / 10.36 s n$ & $C l=\left(C+k_{t r}\right) / d$ & $\begin{array}{c}\text { Ultimate } \\
\text { Load, } \mathrm{kN}^{a}\end{array}$ & $\begin{array}{c}\text { Normalised } \\
\text { Load, kN }\end{array}$ & $\begin{array}{c}\text { Deflection @ } \\
\text { ultimate load, mm }\end{array}$ & $\begin{array}{c}\text { Spliced/ } \\
\text { Unspliced }\end{array}$ & \begin{tabular}{c}
$\mathrm{C} / \mathrm{U}$ \\
\hline UNC100
\end{tabular} \\
\hline C100 & 20.00 & 1.8 & 120.32 & 123.75 & 21.25 & 0.75 & - \\
UNC200 & 20.00 & 1.8 & 109.16 & 112.32 & 18.17 & 0.68 & 0.93 \\
C200 & 10.00 & 1.4 & 96.28 & 97.31 & 15.50 & 0.60 & - \\
UNC300 & 10.00 & 1.4 & 69.68 & 68.52 & 10.75 & 0.43 & 0.72 \\
C300 & 6.67 & 1.26 & 93.19 & 91.62 & 11.19 & 0.58 & - \\
Unspliced & 6.67 & 1.26 & 55.01 & 55.60 & 7.89 & 0.34 & 0.60 \\
\hline
\end{tabular}

${ }^{a}$ Ultimate load normalized @ $60 \mathrm{MPa}$. Normalized load = ultimate load $*\left(\sqrt[4]{60} / \sqrt[4]{f_{c m}}\right)$.

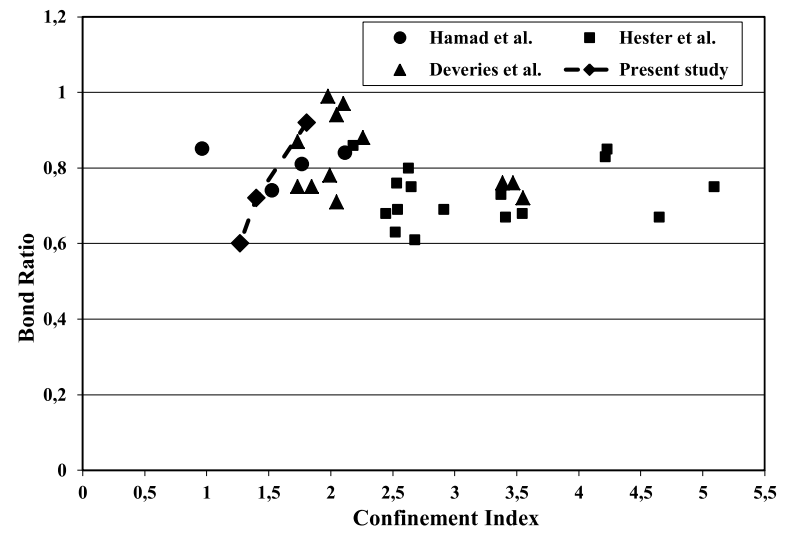

Figure 7. Load-Deflection curves for beams with $8 \mathrm{~mm}$ stirrups spaced@ 100.

epoxy coated bars consistently failed at loads lower than those of the beams with uncoated bars. The ultimate load in beams with coated bars is $7 \%, 28 \%$ and $41 \%$ less than that of beams with uncoated bars for $\mathrm{Cl}$ of for confinement indices $1.8,1.4$ and 1.26 respectively. The ratio of ultimate load carried by spliced beams to that of un-spliced beams is reported in Table 3. The ultimate load in beams with spliced uncoated bars is $75 \%, 60 \%$ and $58.24 \%$ of un-spliced beams for confinement indices of 1.8, 1.4 and 1.26 respectively. The ultimate load in beams with spliced coated bars is $68 \%, 43.55 \%$ and $34 \%$ of un-spliced beams for confinement indices of $1.8,1.4$ and 1.26 respectively.

Confining the lap splices with 8 mm stirrups @ 100 mm spacing doubles the bond strength of lap splices with coated bars confined with 8 mm stirrups @ 300 mm spacing. Hence, transverse reinforcement reduces the negative impact of fusion bonded epoxy coating on the bond strength [10].

The initial stiffness of all the beams before cracking appears to be the same. After cracking of beams, the stiffness of the beams with higher confinement in splice region has been found to be larger than the beams with nominal confinement in splice region.
Table 4. Number of cracks and average spacing of cracks.

\begin{tabular}{lcc}
\hline Beam Id & $\begin{array}{c}\text { Average Crack Spacing, } \\
\text { cm }\end{array}$ & No. of Cracks \\
\hline \hline UNC100 & 13.5 & 21 \\
C100 & 13.6 & 20 \\
UNC200 & 13.2 & 19 \\
C200 & 14.7 & 18 \\
UNC300 & 11.9 & 21 \\
C300 & 17.0 & 13 \\
\hline
\end{tabular}

As the load on the beam was increased further, flexural cracks formed initially at the end of the splices. Subsequently, several flexural cracks were formed all along the beam. Inclined cracks were not observed, proving that the failure of the beams was due to flexure rather than shear. Splitting cracks along the splice were also observed. Eventually, the beams failed due to crushing of concrete in compression zone. As the loading on the beams progressed, flexural cracks were formed initially at the ends of the splice. Upon further increase in the load, more hairline cracks were formed in between the ends of splice until the ultimate load is reached. Diagonal cracks did not form in the beams as the beams were designed to fail in bond. The formation of several vertical cracks is followed by horizontal cracks along the splice at the ultimate load. The lateral confinement was effective in controlling the opening of splitting cracks. However, it had little control over the opening of the vertical cracks as the cracks were formed parallel to the stirrups. It could be seen that the number of flexural cracks decreased as the confinement index decreased. Similarly, the average spacing between the cracks increases as the confinement index decreases. Furthermore, the crack spacing and the crack-width in beams reinforced with coated bars are found to be larger than beams with uncoated bars. The number of cracks and the spacing of cracks are reported in Table 4. The cracking pattern in beams reinforced with the coated bars is shown in Figure 8. 


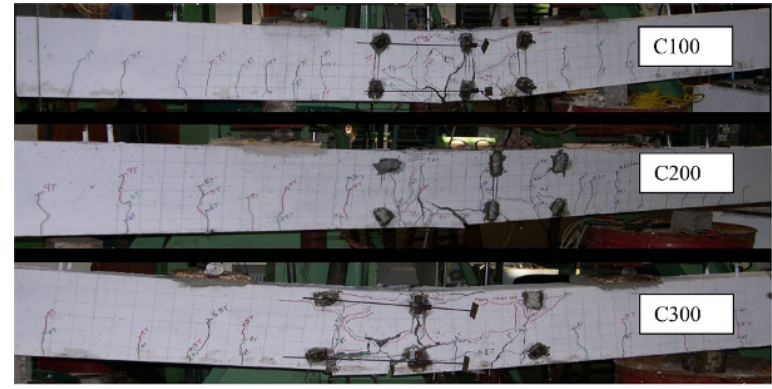

Figure 8. Formation of cracks in coated beams.

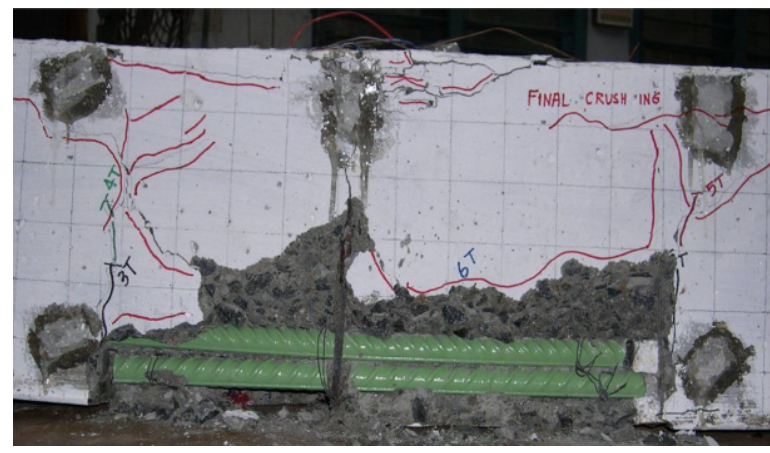

Figure 9. Splitting failure of beam with epoxy coating.

After completion of the testing of the beam, the concrete cover to the reinforcement was removed for investigating the nature of adhesion between the reinforcement and the surrounding concrete. The splice region without cover concrete is shown in Figure 8. It is found that the mode of bond failure is splitting along the interface of coated bar and concrete and this has not initiated crushing of concrete at the ribs of the bars. Also, the beams with coated bars had no traces of concrete adhering to it. Moreover, the epoxy coating was not damaged indicating that the adhesion between the bar and concrete is negligible. Conversely, in the beams with uncoated bars, the crushing of concrete was observed in front of the ribs of the bar. Similar observations have been reported by Treece and Jirsa [1], Hester et al. [8], Choi et al. [9].

\section{Ductility of the beams with rein- forcement splice}

The confinement provided to the beams not only increased the splice strength of the splice but also the ductility of the beam. The ductility of the beams is quantified by calculating the toughness of the beam, which is found by calculating the area under the load-deflection curve. The
Table 5. Ductility ratio.

\begin{tabular}{lcc}
\hline Beam & $\begin{array}{c}\text { Toughness, } \\
\text { Designation }\end{array}$ & Ductility ratio \\
\hline UNC100 & 1672 & \\
C100 & 1552 & - \\
UNC200 & 1004 & 0.928 \\
C200 & 802 & - \\
UNC300 & 832 & 0.798 \\
C300 & 680 & - \\
\hline
\end{tabular}

testing of the beams was terminated at different post peak loads and was not carried out until the load dropped to zero. Hence, to have a common upper limit to calculate the area under the load-deflection curve, the area under the curve was calculated by fixing the upper limit of deflection as span/150. Based on this upper limit, the area under the load-deflection curve is calculated and reported in Table 5. The ductility ratio as defined given by Equation (1) is used to find out the effect of coating on ductility of the beams with reinforcement splices.

Ductility Ratio $=\frac{\text { Ductility of beams with coated bars }}{\text { Ductility of beams with uncoated bars }}$

The toughness of the beams with splices confined with 2 legged 8 mm stirrups @ 100 is relatively better than similar beams with splices confined with 2 legged $8 \mathrm{~mm}$ stirrups @ 200 and @ 300, irrespective of coating. The coating on the bars reduces the toughness of the beams. However, the reduction in toughness is $7 \%$ in splices confined with 2 legged 8 mm stirrups @ 100. But, the reduction in splices confined with 2 legged 8 mm stirrups @ 200 and @ 300 is around $20 \%$. Hence, confinement of the splice has a significant effect on the ductility of the beams.

\section{Effect of lateral confinement}

The confining effect is represented in terms of an equivalent cover to diameter ratio referred to as confinement index $(C I)[14]$ and is calculated using Equation (2).

$$
\text { Confinement Index }(C I)=\left(\frac{c+k_{t r}}{d_{b}}\right)
$$

where $c=$ minimum cover in $\mathrm{mm} ; d_{b}=$ diameter of the bar in $\mathrm{mm} ; k_{t r}=$ transverse reinforcement index to indicate the amount of transverse reinforcement crossing the potential splitting plane in the splice region and calculated using Equation (3).

$$
k_{t r}=\frac{A_{t r} f_{y t}}{10.36 s n}
$$


where $A_{t r}=$ total cross-sectional area of the transverse reinforcement that is provided within spacing, $s$ and to cross the potential plane of splitting, $\mathrm{mm}^{2} f_{y t}=$ specified yield strength of transverse reinforcement in $\mathrm{MPa}, n=$ number of bars being spliced along the plane of splitting and $s=$ center-to-center spacing of transverse reinforcement within the splice length in $\mathrm{mm}$.

Confinement is provided by two factors viz., the cover concrete and the transverse reinforcement. Confinement index is considered as the ratio of sum of concrete cover and equivalent cover provided by the transverse reinforcement $k_{t r}$ to the diameter of the bar. In which, $k_{t r}$ represents the confinement effect of reinforcement $k_{t r}$ is directly proportional to the area of transverse reinforcement and the stress in the stirrup. $k_{t r}$ is inversely proportional to the spacing of the stirrups and the number of spliced bars confined by the stirrups. If the value of $C I$ is less than 3.0, then the beam is confined less and the failure will be due to splitting of concrete. Otherwise, the bars are well confined and the mode of failure will be by pullout of the bar from the concrete [3]. The calculated values of $C I$ for the spliced beams are furnished in Table 3. The failure of the beams with $C l$ equal to 1.26 was catastrophic and sudden. As a result, the load suddenly drops by more than $50 \%$ of the peak load after the ultimate load. In beams with $C I$ equal to 1.4 , the failure will be relatively less brittle with gradual degradation of load carrying capacity. However, the failure is relatively ductile in beams with $\mathrm{Cl}$ equal to 1.8. Hence, the increase in $\mathrm{Cl}$ from 1.26 to 1.8 increases the strength of the beams with spliced coated bars from $60 \%$ to $93 \%$ of spliced uncoated bars respectively. Similarly, the ductility of the beams with spliced coated bars increases from $80 \%$ to $92.8 \%$ respectively.

The concrete above the neutral axis is in compression with the maximum stress at the topmost fiber of the beam due to the application of constant moment. The longitudinal compressive strain induces a tensile strain in the lateral direction of the beam due to Poisson's effect. The unconfined concrete fails by splitting due to the induced tensile strength exceeding the cracking strain. However, the presence of lateral reinforcement (stirrups) imposes a constraint to the expansion in the lateral direction which induces an equivalent compressive stress in the lateral direction. This in turn, increases the participation of bar lugs in transferring the stresses between the longitudinal bars and the surrounding concrete.

Figure 10 shows the variation of strain in the stirrups at the ultimate load. The strains at the left end centre and right end of the splice are given in Table 6. It is evident that the strain in the stirrup at the centre is more than the strain in the stirrups at the ends in beams with confinement of $8 \mathrm{~mm} @ 300$ mm (Figure 10). This represents the condition

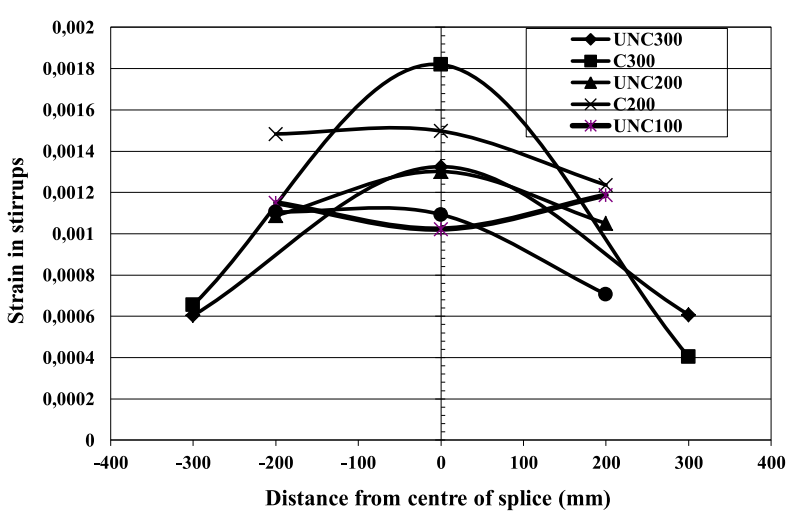

Figure 10. Strain distribution in stirrups.

Table 6. Variation of strain along the splice.

\begin{tabular}{lccc}
\hline $\begin{array}{l}\text { Beam } \\
\text { Designation }\end{array}$ & $\begin{array}{c}\text { Strain at the } \\
\text { left end of the } \\
\text { splice }\end{array}$ & $\begin{array}{c}\text { Strain at the } \\
\text { centre of the } \\
\text { splice }\end{array}$ & $\begin{array}{c}\text { Strain at the } \\
\text { right end of } \\
\text { the splice }\end{array}$ \\
\hline \hline UNC100 & 0.001150 & 0.001023 & 0.001187 \\
C100 & 0.001106 & 0.001093 & 0.000707 \\
UNC200 & 0.001089 & 0.001302 & 0.001050 \\
C200 & 0.001483 & 0.001497 & 0.001236 \\
UNC300 & 0.000604 & 0.001325 & 0.000608 \\
C300 & 0.000656 & 0.001819 & 0.000404 \\
\hline
\end{tabular}

similar to an unconfined concrete i.e. concrete confined only by the cover concrete and not by the transverse reinforcement. The ends of the splice in beams UNC300 and C300 are not confined with stirrups and hence the ultimate loads are very low in these beams indicating the importance of providing stirrups at the end of the splice. However, in the case of beams with $8 \mathrm{~mm}$ stirrups spaced at $200 \mathrm{~mm}$ and $100 \mathrm{~mm}$, the straining of concrete due to the splitting is carried by all the stirrups in the splice region.

Even at low confinement, the stirrups have not yielded as the stress in the steel bar is less than the yield stress of the bar. This indicates that the yield strength of the stirrups has no influence on the level of confinement provided. However, the strain in the bars is invariably high in the beams with coated bars than the uncoated bars. The reason could be the increase in angle of inclination of the wedging forces at the ribs. As the angle of the wedging force increases, the magnitude of the radial stress component increases. The increase in the magnitude of radial stress component requires additional confinement. This in turn, increases the stress in the stirrups in beams with coated bars than uncoated bars. 


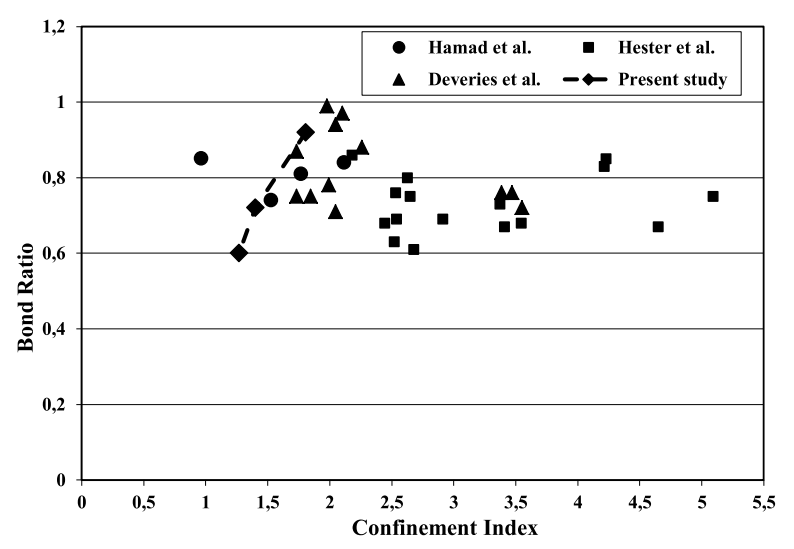

Figure 11. Effect of confinement on bond ratio.

\section{Calculation of bond stress}

The beams were designed to fail in bond before yielding of the tension reinforcement. Since it is difficult to measure the bond stress directly from the experiments; the bond stress is calculated by the elastic cracked section analysis. The variation of bond stress along the splice length is assumed to be constant and calculated using Equation (4) as specified in $\mathrm{ACl} 408$ [3].

$$
u=\frac{P}{\pi d_{b} l_{s}}
$$

where $P=$ force in the bar in $\mathrm{N} d_{b}=$ diameter of the bar in $\mathrm{mm} l_{\mathrm{s}}=$ splice length in $\mathrm{mm}$.

There was an improvement of the bond ratio as the lateral confinement increases. The calculated bond ratio is 0.93 , 0.72 and 0.59 for confinement indices of $1.8,1.4$ and 1.26 respectively.

An attempt has been made to compare the results of the present study with the available literature on the effect of confinement in improving the bond ratio (Figure 11). In the present work, the level of confinement provided to the bars is less than that reported in literature. It is evident from the Figure 11 that the bond ratio is increased at low levels of confinement ( $C I$ is less than 2.0). However, bond ratio does not increase significantly with further increase in confinement. Hester et al. [8] reported that the effect of confinement in increasing the splice strength of coated bars is negligible. This may be true only at high levels of confinement. However, at low level of confinement, up to a $\mathrm{Cl}$ of 2.0, splice strength depends on the degree of confinement. Transverse reinforcement also reduces the negative impact of fusion bonded epoxy coating on the bond strength [10].

\section{Comparison with orangun, jirsa and breen (OJB) model}

OJB model [22] is one of the most commonly known expressions for evaluating the average bond strength of developed or spliced bars in tension. The expression was derived based on regression analysis of experimental data of spliced bars embedded in normally vibrated concrete. It was adopted by the $\mathrm{ACl}$ building code for computing the development or splice lengths of steel bars in tension.The $\mathrm{OJB}$ model is given in Equation (11):

$$
\frac{u, O J B}{\sqrt{f^{\prime} C}}=0.1+0.25 \frac{c}{d_{b}}+4.15 \frac{d_{b}}{l_{s}}+\frac{A_{t r} f_{y t}}{41.6 s n_{s} d_{b}}
$$

where $u, O J B=$ average bond strength at bond failure in $\mathrm{MPa} ; f_{c}^{\prime}=$ concrete compressive strength in $\mathrm{MPa} ; c=$ smaller of side cover, bottom cover, or one-half the clear distance between the bars in $\mathrm{mm} ; l_{s}=$ development or splice length in $\mathrm{mm}$ and $d_{b}=$ diameter of steel bar in $\mathrm{mm}$; $A_{t r}, s$ and $f_{y t}=$ area in $\mathrm{mm}^{2}$, spacing in $\mathrm{mm}$, and yield stress of transverse steel reinforcement in MPa, crossing the potential plane of splitting,respectively; $n_{s}=$ number of spliced or developed bars.

The average bond strength, $u, O B$ f for the beams is calculated as per the above expression and is reported in Table 7. A reduction factor of 1.5 as suggested in $\mathrm{ACl} 408$ [3] committee is used in the above expression to calculate the bond strength of coated bars. A reduction factor of 1.5 predicts the bond strength well for splices with confinement index less than 1.4. However for splices with confinement index greater that 1.4 , the reduction factor of 1.5 seems to be high and hence a reduction factor of 1.35 is suggested.

\section{Conclusions}

From the limited study carried out with six numbers of beams with splices in the constant moment region with $C / d_{b}$ ratio 1.0 and $L_{d} / d_{b}$ ratio 16 , to study the influence of confinement by stirrups on the bond strength of coated and uncoated bars, the following conclusions were drawn:

1. Epoxy coating significantly reduces the splice strength of deformed reinforcing bars in concrete. The percentage decrease in strength caused by epoxy coating is dependent on the degree of transverse reinforcement. Lateral confinement improves the ductility of beams with splices in both the coated and uncoated bars. The reduction in toughness due to epoxy coating is only $7 \%$ in the presence of transverse reinforcement amounting to a confinement index of 1.80 . However, when the confinement 
Table 7. Test/OJB predicted ratio of bond stress.

\begin{tabular}{|c|c|c|c|c|c|c|c|c|}
\hline \multirow[t]{2}{*}{$\begin{array}{l}\text { Beam } \\
\text { Designation }\end{array}$} & \multirow[t]{2}{*}{$\begin{array}{l}\text { u,Expt, } \\
\mathrm{MPa}\end{array}$} & \multirow[t]{2}{*}{$\begin{array}{c}C l= \\
(C+K t r) d\end{array}$} & \multicolumn{2}{|c|}{ Uncoated bar } & \multicolumn{2}{|c|}{$\begin{array}{c}\text { Coated bar, } \\
\text { with } \psi=1.50\end{array}$} & \multicolumn{2}{|c|}{$\begin{array}{c}\text { Coated bar, } \\
\text { with } \psi=1.35\end{array}$} \\
\hline & & & $u, O J B, \mathrm{MPa}$ & $u, O J B / u, \operatorname{Expt}$ & $u, O J B, \mathrm{MPa}$ & $u, O J B / u, \operatorname{Expt}$ & $u, O J B, \mathrm{MPa}$ & $u, O J B / u$, Expt \\
\hline UNC100 & 3.65 & 1.8 & 5.25 & 1.44 & - & - & - & - \\
\hline C100 & 3.91 & 1.8 & - & - & 3.50 & 0.89 & 3.88 & 0.99 \\
\hline UNC200 & 2.26 & 1.4 & 4.62 & 2.04 & - & - & - & - \\
\hline C200 & 3.12 & 1.4 & - & - & 3.08 & 0.98 & 3.42 & 1.09 \\
\hline UNC300 & 1.78 & 1.26 & 4.41 & 2.48 & - & - & - & - \\
\hline C300 & 3.02 & 1.26 & - & - & 2.94 & 0.97 & 3.26 & 1.07 \\
\hline
\end{tabular}

index is less than 1.40, the reduction in toughness is around $20 \%$.

2. Bond strength of epoxy coated $25 \mathrm{~mm}$ bar splices relative to uncoated bar splices improved from $60 \%$ in the presence of transverse reinforcement amounting to a confinement index of 1.26 to around $93 \%$ when the confinement index increased to 1.80 .

3. It is seen from the experimental observations that OJB model overestimates the bond strength of uncoated bars. The present investigation also proves that the reduction factor of 1.35 . is more realistic for splices with confinement index greater that 1.4 .

4. Further investigations on the effect of coating and confinement on the splice strength of fusion bonded epoxy coated bars under cyclic loading is needed to study the degradation of strength, stiffness and energy absorption due to coating.

\section{References}

[1] Treece R.A., Jirsa J.O., Bond strength of epoxy-coated reinforcing bars, ACl Material Journal, 1989, 86, 167174

[2] Cairns J., Abdullah R., Fundamental tests on the effect of epoxy coating on bond strength, $\mathrm{ACl}$ Material Journal, 1994, 91, 331-338

[3] $\mathrm{ACl}$ Committee 408R., Bond and development of straight reinforcing bars in tension, American Concrete Institute, Detroit, USA, 2003

[4] Azizinamini A., Pavel R.,Hatfield E., Ghosh S.K.,Behaviour of spliced reinforcing bars embedded in high-strength concrete, ACl Structural Journal, 1999, 96, 826-835

[5] Harajli M.H., Comparison of bond strength of steel bars in normal and high strength concrete, ASCE Journal of Materials in Civil Engineering, 2004, 16, 365-374
[6] Hamed B.S., Rteil A.A., Comparison of roles of FRP sheets, stirrups and steel fibres in confining bond critical regions, ASCE Journal of Composites for Construction, 2006, 10, 330-336

[7] Swamy R.N., Epoxy coated rebars-the panacea for steel corrosion in concrete, Construction and Building Materials, 1989, 3, 86-91

[8] Hester C.J., Salamizavareh S., Darwin D., Mc Cabe S.L., Bond of epoxy-coated reinforcement: Splices, ACI Structural Journal, 1993, 90, 89-102

[9] Choi O.C., Ghaffari H.H., Darwin D., Mc Cabe S.L., Bond of epoxy-coated reinforcement: Bar parameters, ACl Materials Journal, 1991, 88, 207-217

[10] Hamad B.S., Jirsa J.O., Strength of epoxy coated reinforcing bar splices confined with transverse reinforcement, ACl Structural Journal, 1993, 90, 77-88

[11] Abrishami H.H, Cook W.D., Mitchell D., Influence of epoxy-coated reinforcement on response of normal and high strength concrete beams, ACl Structural Journal, 1995, 92, 157-166

[12] Idun E.K., Darwin D., Bond of epoxy coated reinforcement: Coefficient of friction and rib face angle, $\mathrm{ACl}$ Structural Journal, 1999, 96, 609-615

[13] Cairns J., Abdullah R.B., Influence of rib geometry on strength of epoxy-coated reinforcement, $\mathrm{ACl}$ Structural Journal, 1995, 92, 23-27

[14] ACl Committee 318, Building code requirement for reinforced concrete and commentary ( $\mathrm{ACl}-318-05)$, American Concrete Institute, Detroit, USA, 1995

[15] AASTHO Highway sub-committee on bridges and structures, Standard specification for Highway bridges, $14^{\text {th }}$ ed., American Association of state Highway and Transportation Officials, Washington, DC, USA, 1989

[16] IS 10262-2009, Recommended guidelines for concrete mix design, Bureau of Indian Standards, New Delhi, India, 2009

[17] IS 12269-1987,Specification for 53 grade ordinary port-land cement, Bureau of Indian Standards, New Delhi, India, 1987 
[18] IS 383-1970, Specification for coarse and fine aggregates from natural sources for concrete (Second Revision), Bureau of Indian Standards, New Delhi, India, 1970

[19] IS 1786-2008, Specification for high strength deformed steel bars and wires for concrete reinforcement, Bureau of Indian standards, New Delhi, India, 2008

[20] IS 13620-1993,Specification for fusion bonded epoxy coated reinforcing bars, Bureau of Indian Standards, New Delhi, India, 1993
[21] Pandurangan K., Experimental studies on effect of fusion bonded epoxy-coated bars on bond and cracking behavior of reinforced concrete, $\mathrm{PhD}$ thesis, Indian Institute of Technology Madras, Chennai, India, 2010.

[22] Orangun C.O., Jirsa J.O., Breen J.E., Re-evaluation of test data on development length and splices, $\mathrm{ACl}$ Journal, 1977, 74, 114-122 